\title{
COMPARISON OF COMPUTERISATION AND INNOVATION ACTIVITY OF THE COMPANIES IN RURAL AND URBAN AREAS
}

\author{
Marek Angowski, Department of Management and Marketing, University of Life Sciences in Lublin, 20-950 Lublin, ul. \\ Akademicka 13, Poland, marek.angowski@up.lublin.pl \\ Aneta JAROSZ-ANGOWSKA, Department of Economy and Agribusiness, University of Life Sciences in Lublin, 20-950 Lublin, \\ ul. Akademicka 13, Poland, aneta.angowska@up.lublin.pl \\ Marcin LIPOWSKI, Department of Marketing, University of Maria Curie-Sklodowska in Lublin, 20-950 Lublin, ul. Akademicka \\ 13, Poland, marcin.lipowski@gmail.com
}

\begin{abstract}
Over the last years, the economic and social structure of enterprises has undergone some important changes, especially because of the introduction of Information and Communication Technologies (ICTs). ICT is one of the fundamental elements driving the innovation and competitiveness of business activities which greatly influences the development of rural areas, both in economic and social terms. This publication focuses on the analysis and evaluation of the use of ICTs by enterprises in the Lubelskie Voivodeship with particular emphasis on rural areas. In the publication the authors use statistical analyses based on information from surveys conducted among entrepreneurs by the Marshal Office of the Lubelskie Voivodeship. The paper evaluates the following issues: the degree of computerisation of the company, the use of information technology in the company, the activity of the company on the Internet. The main objective of this study is to identify the relationship between the degree of computerisation and the company's innovation-oriented activities and to identify differences between companies located in urban and rural areas. The studies carried out have demonstrated that the differences in the computerisation of enterprises located in rural and urban areas are negligible and that there is a close relationship between the degree of computerisation and innovation in enterprises located in rural areas.
\end{abstract}

Keywords: enterprises, information and communication technology, innovation, internet, rural and urban areas.

\section{INTRODUCTION}

The term information technology (ICT), also known as information and telecommunications or data communications, is understood as technologies for the electronic and digital processing, gathering and transmitting of information, mostly via computer networks, mainly the Internet (Macik, 2013). These include in particular computer technology (hardware and software) and communication technologies. Information technology is also the area of knowledge which includes: information science, telecommunications and other technologies connected with information. They provide the tools that can be used to obtain information, select it, analyse, process and transmit to recipients (Matusiak, 2011).

ICT takes on the main role in the economy transformation process as well as in the creation of a vital source of competitiveness for enterprises (Pena et al., 2011). ICT has a positive effect on the productivity and flexibility of companies, to adapt to contingencies of the market, enabling the tailoring of their packages to the needs of the market. This has become especially relevant in the recent years, as due to globalisation companies are facing significant challenges originating from an increase in competitiveness on the markets, the appearance of new products and the higher expectations of consumers (Chen et al., 2013; Ollo-Lopez, 2012; Tarute et al., 2014).

Information and Communication Technologies (ICTs) are an important factor conditioning development in the modern world, supporting the flow of data, services and people. Economic growth is based on technology, innovation and, more broadly, knowledge. In addition, Information and Communication Technologies (ICTs) are key tools in promoting innovation-oriented activities, technology diffusion, and knowledge generation within societies (Kijek et al., 2010). Indeed, as Information Society paradigm matures, the effective use of ICTs becomes an indispensable measure in promoting sustainable growth (Avgerou, 2010; Balboni et al., 2011; Jarosz-Angowska et al., 2014).

The role of ICTs in rural areas is substantial and it is steadily growing. No change in the functioning and improvement in the social and economic situation of individual areas is possible without the use of the infrastructure of the 21 st century - the Internet. The Internet facilitates access to endless data resources deposited over the world (regardless of their spatial location), and it also streamlines communication. The Internet stands as one of the important factors expediting the socio-economic development of rural areas. It makes it possible to gain knowledge, improve education or

Copyright (C) 2015 The Authors. Published by Aleksandras Stulginskis University. This is an open-access article distributed under the terms of the Creative Commons Attribution License (CC-BY 4.0), which permits unrestricted use, distribution, and reproduction in any medium, provided the original author and source are credited. 
even legitimately earn a certain level of education, while eliminating the inconveniences associated with the remoteness of rural areas (Czapiewski et al., 2012; Sawicka, 2010; Tripathi, et al., 2012).

The impact of the Internet on businesses and on consumers is significant regardless of the location and type of enterprise, and while this is observable throughout social and economic life, especially in respect of businesses many theories and speculations have emerged. When it comes to small enterprises, democracy facilitated by the Internet has been theorised as affording greater competitiveness by providing a more level playing field in terms of visibility, profile and market opportunities previously characteristic of large companies with sufficient resources for these. For rural entities particularly, the Internet is further theorised as having the capacity to reduce the disadvantages inherent in rural locations, such as isolation from markets, relatively weaker networking and support provision, and indeed, the increasing profile of and competition from external web-based providers (Galloway et al., 2011; Nayak et al., 2010).

In accordance with the Millennium Development Goals (MDGs), the 2003 phase of the World Summit on the Information Society (WSIS) held in Geneva agreed on a Declaration of Principles and a Plan of Action, setting ten targets and several action lines to be achieved by 2015. The targets put forward under the Plan of Action aim, inter alia, at improving ICT connectivity in villages (Measuring the Information Society, 2014).

The main goal of the study was to identify, analyze and assess the computerization of companies in the Lubelskie Voivodeship and the relationship between the level of company computerization and its innovativeness. Authors made comparison between rural and urban areas taking into account the characteristics of the company - its size, sectors and operating range.

\section{RESEARCH METHODS}

The presented results and the analysis are based on the research project entitled "The Intellectual Capital of the Lubelskie Region 2010-2013." It was conducted by the Statistical Office in Lublin at the request of the Marshal Office of the Lubelskie Voivodeship under Priority VIII Regional Human Resources, Measure 8.2 Transfer of Knowledge, SubMeasure 8.2.2 Regional Innovation Strategies of the Human Capital Programme for the years 2007-2013.

The research was conducted in 2013 on a representative sample of 650 companies from the Lubelskie Voivodeship, drawn from the National Official Business Register (REGON, Central Statistical Office). An additional criterion for selection was the proportion of companies registered in the voivodeship, with the division into small, medium-sized and large companies, taking into account the specific ratio of each county.

Among 650 surveyed companies $79.5 \%$ were located in cities and $20.5 \%$ were located in rural areas.

Table 1. Characteristics of the research sample

\begin{tabular}{|c|c|c|c|c|}
\hline \multirow{2}{*}{\multicolumn{2}{|c|}{ Characteristics }} & \multicolumn{3}{|c|}{ Localization of enterprises } \\
\hline & & Total & Rural areas & City \\
\hline \multirow{4}{*}{ 总 } & services & $38.0 \%$ & $27.1 \%$ & $40.8 \%$ \\
\hline & trade & $23.7 \%$ & $23.3 \%$ & $23.8 \%$ \\
\hline & production & $26.8 \%$ & $41.4 \%$ & $23.0 \%$ \\
\hline & other & $11.5 \%$ & $8.3 \%$ & $12.4 \%$ \\
\hline \multirow{4}{*}{ 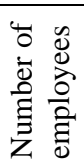 } & micro & $14.9 \%$ & $203 \%$ & $13.5 \%$ \\
\hline & little & $46.3 \%$ & $51.9 \%$ & $44.9 \%$ \\
\hline & medium & $30.9 \%$ & $24.1 \%$ & $32.7 \%$ \\
\hline & large & $7.8 \%$ & $3.8 \%$ & $8.9 \%$ \\
\hline \multirow{4}{*}{ 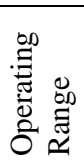 } & locally and region & $73.1 \%$ & $78.9 \%$ & $71.6 \%$ \\
\hline & country & $61.4 \%$ & $63.9 \%$ & $60.7 \%$ \\
\hline & EU & $32.6 \%$ & $28.5 \%$ & $33.7 \%$ \\
\hline & world & $17.4 \%$ & $16.5 \%$ & $17.6 \%$ \\
\hline
\end{tabular}

Source: Survey results

\section{RESEARCH RESULTS}

The comparison of the degree of computerisation of rural and urban areas has demonstrated that companies located in rural areas to a greater extent make use of basic computer software (38.3\% of companies) compared to companies located in urban areas (37.3\% of companies). Companies located in urban areas more often make use of specialised software tailored to the business (52.4\% compared to $51.9 \%$ of enterprises in rural areas). $10.3 \%$ of the surveyed companies located in urban areas had in place an integrated IT system, while such a system was implemented in $9.8 \%$ of companies located in rural areas.

The largest number of enterprises operating in rural areas and using basic software is located in the services sector, while companies which benefit from specialised computer software are located mainly in the trade sector, which is presented in Table 2. The degree of computerisation of the company increases with the size of the company. $66.7 \%$ of micro-enterprises use basic computer software, $78.1 \%$ of medium-sized companies use specialised computer software, and up to $80 \%$ of large companies have implemented an integrated information system. 
Table 2. Characteristics of the degree of firm computerization against the main profile of activity, number of employees and the range of activities

\begin{tabular}{|c|c|c|c|c|}
\hline & \multirow[b]{2}{*}{ Characteristics } & \multicolumn{3}{|c|}{ The degree of computerization of the company from rural areas } \\
\hline & & $\begin{array}{l}\text { The company makes use of } \\
\text { basic computer software }\end{array}$ & $\begin{array}{c}\text { The company uses specialized } \\
\text { software tailored to the } \\
\text { business }\end{array}$ & $\begin{array}{l}\text { The company has implemented an } \\
\text { integrated information system }\end{array}$ \\
\hline & services & $50.0 \%$ & $44.4 \%$ & $5.6 \%$ \\
\hline d. & trade & $35.5 \%$ & $61.3 \%$ & $3.2 \%$ \\
\hline 责 & production & $30.9 \%$ & $52.7 \%$ & $16.4 \%$ \\
\hline $\bar{\varphi}$ & other & $45.5 \%$ & $45.5 \%$ & $9.1 \%$ \\
\hline 4 & micro & $66.7 \%$ & $33.3 \%$ & $0.0 \%$ \\
\hline$\overline{\mathrm{d}}$ & little & $44.9 \%$ & $49.3 \%$ & $5.8 \%$ \\
\hline है & medium & $6.3 \%$ & $78.1 \%$ & $15.6 \%$ \\
\hline Z & large & $0.0 \%$ & $20.0 \%$ & $80.0 \%$ \\
\hline a & locally and region & $39.0 \%$ & $48.6 \%$ & $12.4 \%$ \\
\hline 鞄 & country & $36.5 \%$ & $48.2 \%$ & $15.3 \%$ \\
\hline 跑 & EU & $15.8 \%$ & $57.9 \%$ & $26.3 \%$ \\
\hline कै & world & $31.8 \%$ & $45.5 \%$ & $22.7 \%$ \\
\hline
\end{tabular}

An analysis of modern ICT technologies in the surveyed companies showed that $53.4 \%$ of companies located in rural areas and $63.8 \%$ of companies located in urban areas own a server. $36.8 \%$ of companies located in rural areas and $30.9 \%$ of companies located in urban areas access the Internet using an analog modem, while respectively $54.9 \%$ and $61.7 \%$ of companies access the Internet via a broadband connection. $35.3 \%$ of companies located in rural areas and $46.8 \%$ of urban companies have a LAN-type internal computer network, $33.1 \%$ of companies located in rural areas and $28.8 \%$ of companies located in urban areas have internal wireless networks and respectively $13.5 \%$ and $19.7 \%$ of companies in rural and urban areas have the internal intranet. $1.5 \%$ of companies from rural areas and $3.1 \%$ of companies from urban areas are connected to the extranet. The use of e-mail accounts for business purposes is quite large $-63.2 \%$ in rural areas and $71.4 \%$ in urban areas. $6.8 \%$ of companies in rural areas use VoIP - voice over IP or ERP, while such systems are used by $8.3 \%$ of companies in urban areas. Companies in urban areas to a greater extent facilitate remote access to corporate resources - such access is provided by $23 \%$ of companies in the cities and $18.8 \%$ of companies in rural regions. Table 3 below presents modern ICTs in the surveyed companies in rural regions by the main profile of activity, number of employees and the range of activities.

Table 3. Modern ICT in the surveyed companies from rural areas against the main profile of activity, number of employees and the range of activities

\begin{tabular}{|c|c|c|c|c|c|c|c|c|c|c|c|}
\hline \multirow{2}{*}{\multicolumn{2}{|c|}{ Characteristic }} & \multicolumn{10}{|c|}{ Modern ICT in the surveyed companies } \\
\hline & & 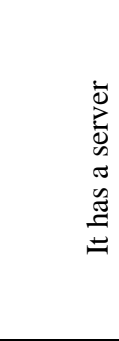 & 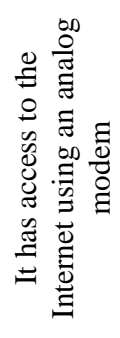 & 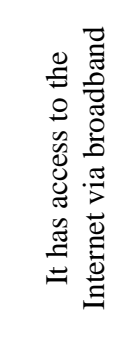 & 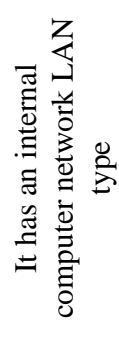 & 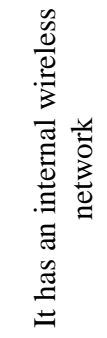 & 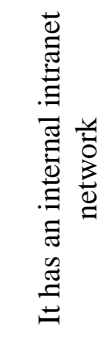 & 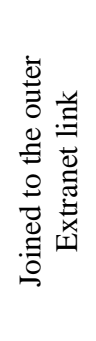 & 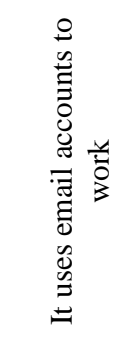 & 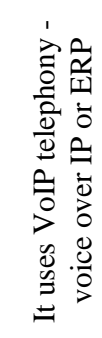 & 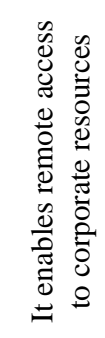 \\
\hline \multirow{4}{*}{ 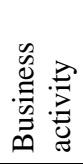 } & services & $44.4 \%$ & $41.7 \%$ & $55.6 \%$ & $38.9 \%$ & $33.3 \%$ & $11.1 \%$ & $0.0 \%$ & $69.4 \%$ & $5.6 \%$ & $16.7 \%$ \\
\hline & \begin{tabular}{|l|} 
trade \\
\end{tabular} & $58.1 \%$ & $25.8 \%$ & $45.2 \%$ & $29.0 \%$ & $25.8 \%$ & $12.9 \%$ & $0.0 \%$ & $48.4 \%$ & $3.2 \%$ & $12.9 \%$ \\
\hline & production & $58.2 \%$ & $40.0 \%$ & $56.4 \%$ & $34.5 \%$ & $38.2 \%$ & $12.7 \%$ & $1.8 \%$ & $67.3 \%$ & $10.9 \%$ & $25.5 \%$ \\
\hline & other & $45.5 \%$ & $36.4 \%$ & $72.7 \%$ & $45.5 \%$ & $27.3 \%$ & $27.3 \%$ & $9.1 \%$ & $63.6 \%$ & $0.0 \%$ & $9.1 \%$ \\
\hline \multirow{4}{*}{ 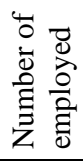 } & micro & $22.2 \%$ & $48.1 \%$ & $37.0 \%$ & $11.1 \%$ & $25.9 \%$ & $3.7 \%$ & $0.0 \%$ & $44.4 \%$ & $0.0 \%$ & $0.0 \%$ \\
\hline & little & $47.8 \%$ & $30.4 \%$ & $58.0 \%$ & $30.4 \%$ & $29.0 \%$ & $8.7 \%$ & $1.4 \%$ & $59.4 \%$ & $7.2 \%$ & $13.0 \%$ \\
\hline & medium & $84.4 \%$ & $37.5 \%$ & $62.5 \%$ & $62.5 \%$ & $46.9 \%$ & $28.1 \%$ & $3.1 \%$ & $81.3 \%$ & $12.5 \%$ & $40.6 \%$ \\
\hline & large & $100.0 \%$ & $60.0 \%$ & $60.0 \%$ & $60.0 \%$ & $40.0 \%$ & $40.0 \%$ & $0.0 \%$ & $100.0 \%$ & $0.0 \%$ & $60.0 \%$ \\
\hline \multirow{4}{*}{ 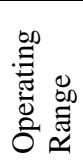 } & locally and region & $53.3 \%$ & $32.4 \%$ & $58.1 \%$ & $33.3 \%$ & $29.5 \%$ & $16.2 \%$ & $1.9 \%$ & $65.7 \%$ & $6.7 \%$ & $18.1 \%$ \\
\hline & \begin{tabular}{|l|} 
country \\
\end{tabular} & $62.4 \%$ & $38.8 \%$ & $56.5 \%$ & $40.0 \%$ & $40.0 \%$ & $15.3 \%$ & $2.4 \%$ & $67.1 \%$ & $10.6 \%$ & $23.5 \%$ \\
\hline & EU & $76.3 \%$ & $28.9 \%$ & $63.2 \%$ & $52.6 \%$ & $44.7 \%$ & $18.4 \%$ & $2.6 \%$ & $78.9 \%$ & $18.4 \%$ & $34.2 \%$ \\
\hline & world & $77.3 \%$ & $36.4 \%$ & $59.1 \%$ & $40.9 \%$ & $45.5 \%$ & $18.2 \%$ & $0.0 \%$ & $81.8 \%$ & $9.1 \%$ & $22.7 \%$ \\
\hline
\end{tabular}

Source: Survey results

Having a website is declared by $60.2 \%$ of companies located in rural areas and $77.2 \%$ of companies located in urban areas. $7.5 \%$ of companies in rural areas and $4.8 \%$ of enterprises in urban areas reported that their websites are under construction. The use of the websites is the most considerable in the trade sector and in other sectors, and it significantly increases with the size of the company $-100 \%$ of large companies declared the utilisation of the website (Table 4). 
Table 4. Having a website in the company from rural areas against the main profile of activity, number of employees and the range of activities

\begin{tabular}{|c|c|c|c|c|}
\hline \multirow{2}{*}{\multicolumn{2}{|c|}{ Characteristic }} & \multicolumn{3}{|c|}{ Website in the company } \\
\hline & & Yes & It is in the making & No \\
\hline \multirow{4}{*}{ 峁 } & services & $55.6 \%$ & $11.1 \%$ & $33.3 \%$ \\
\hline & trade & $61.3 \%$ & $00 \%$ & $38.7 \%$ \\
\hline & production & $56.4 \%$ & $10.9 \%$ & $32.7 \%$ \\
\hline & other & $90.9 \%$ & $00 \%$ & $9.1 \%$ \\
\hline \multirow{4}{*}{ 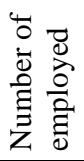 } & micro & $55.6 \%$ & $0.0 \%$ & $44.4 \%$ \\
\hline & little & $50.7 \%$ & $10.1 \%$ & $39.1 \%$ \\
\hline & medium & $78.1 \%$ & $9.4 \%$ & $12.5 \%$ \\
\hline & large & $100.0 \%$ & $0.0 \%$ & $0.0 \%$ \\
\hline \multirow{4}{*}{ 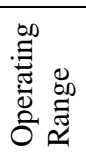 } & locally and region & $61.0 \%$ & $4.8 \%$ & $34.3 \%$ \\
\hline & country & $65.9 \%$ & $9.4 \%$ & $24.7 \%$ \\
\hline & EU & $78.9 \%$ & $10.5 \%$ & $10.5 \%$ \\
\hline & world & $86.4 \%$ & $4.5 \%$ & $9.1 \%$ \\
\hline
\end{tabular}

Doing business over the Internet was declared by $57.3 \%$ of companies in rural areas and by $49.4 \%$ of enterprises in urban areas. First of all, business conducted over the Internet is reported mainly in the services sector. Conducting business over the Internet is affected to a small extent by the size of the company. Companies with a larger territorial range of activity to a greater extent conduct their businesses over the Internet. This is evidenced in Table 5.

Table 5. Running a business through the Internet against the main profile of activity, number of employees and the range of activities

\begin{tabular}{|c|c|c|c|}
\hline \multirow{2}{*}{\multicolumn{2}{|c|}{ Characteristics }} & \multicolumn{2}{|c|}{ Activity through the Internet } \\
\hline & & Yes & No \\
\hline \multirow{4}{*}{ 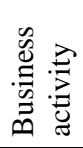 } & services & $58.3 \%$ & $41.7 \%$ \\
\hline & trade & $47.4 \%$ & $52.6 \%$ \\
\hline & production & $55.6 \%$ & $44.4 \%$ \\
\hline & other & $80.0 \%$ & $20.0 \%$ \\
\hline \multirow{4}{*}{ 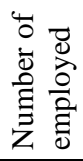 } & micro & $60.0 \%$ & $40.0 \%$ \\
\hline & little & $51.2 \%$ & $48.8 \%$ \\
\hline & medium & $64.3 \%$ & $35.7 \%$ \\
\hline & large & $60.0 \%$ & $40.0 \%$ \\
\hline \multirow{4}{*}{ 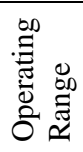 } & locally and region & $58.0 \%$ & $42.0 \%$ \\
\hline & country & $60.9 \%$ & $39.1 \%$ \\
\hline & EU & $66.7 \%$ & $33.3 \%$ \\
\hline & world & $68.4 \%$ & $31.6 \%$ \\
\hline
\end{tabular}

The surveyed companies were asked about the forms of doing business over the Internet. $72.5 \%$ of companies located in rural areas declared that they present catalogues and price lists on the Internet, while this was true for $67.1 \%$ of companies located in urban areas. The forms mentioned included: sending regular newsletters with current packages and special offers $(52.9 \%$ and $52.9 \%$ respectively), enabling users to order products or services of their own design (29.4\% and $28.6 \%)$, on-line ordering and reservation, for example, "basket" or "cart" (9.8\% and 26.2\%), website personalisation for regular users $(5.9 \%$ and $9.5 \%)$, information about vacancies and the option to send application documents over the Internet (19.6\% and $26.7 \%)$. The forms of conducting business over the Internet by companies located in rural areas by the main profile of activity, number of employees and the range of activities is presented in Table 6.

Table 6. Forms of doing business over the Internet against the main profile of activity, number of employees and the range of activities

\begin{tabular}{|c|c|c|c|c|c|c|c|c|}
\hline \multicolumn{2}{|c|}{ Characteristic } & 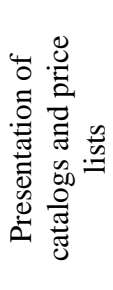 & 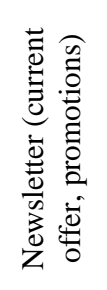 & 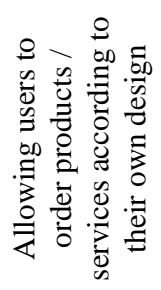 & 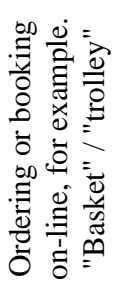 & 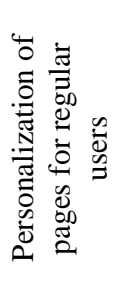 & 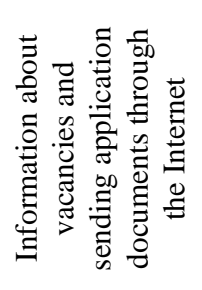 & 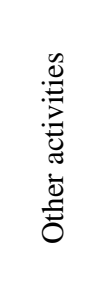 \\
\hline \multirow{4}{*}{ 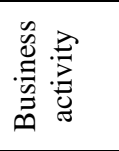 } & services & $64.3 \%$ & $21.4 \%$ & $28,6 \%$ & $7,1 \%$ & $0,0 \%$ & $35,7 \%$ & $14,3 \%$ \\
\hline & trade & $44.4 \%$ & $66.7 \%$ & $55.6 \%$ & $22.2 \%$ & $11.1 \%$ & $11.1 \%$ & $0.0 \%$ \\
\hline & production & $85.0 \%$ & $60.0 \%$ & $25.0 \%$ & $5.0 \%$ & $10.0 \%$ & $15.0 \%$ & $0.0 \%$ \\
\hline & other & $87.5 \%$ & $75.0 \%$ & $12.5 \%$ & $12.5 \%$ & $0.0 \%$ & $12.5 \%$ & $25.0 \%$ \\
\hline \multirow{4}{*}{ 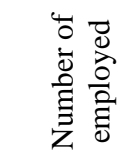 } & micro & $88.9 \%$ & $44.4 \%$ & $11.1 \%$ & $11.1 \%$ & $0.0 \%$ & $11.1 \%$ & $0.0 \%$ \\
\hline & little & $71.4 \%$ & $52.4 \%$ & $33.3 \%$ & $9.5 \%$ & $4.8 \%$ & $23.8 \%$ & $9.5 \%$ \\
\hline & medium & $66.7 \%$ & $55.6 \%$ & $38.9 \%$ & $5.6 \%$ & $5.6 \%$ & $16.7 \%$ & $11.1 \%$ \\
\hline & large & $66.7 \%$ & $66.7 \%$ & $0.0 \%$ & $33.3 \%$ & $33.3 \%$ & $33.3 \%$ & $0.0 \%$ \\
\hline
\end{tabular}




\begin{tabular}{|c|c|c|c|c|c|c|c|c|}
\hline \multicolumn{2}{|c|}{ Characteristic } & 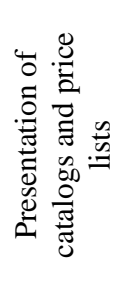 & 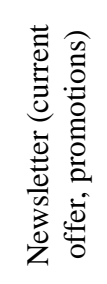 & 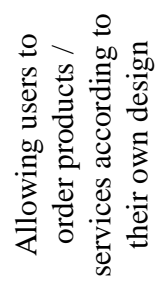 & 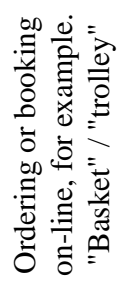 & 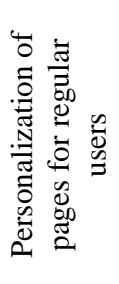 & 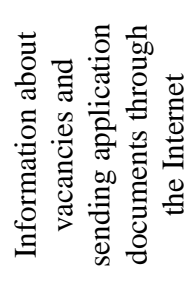 & 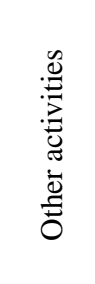 \\
\hline \multirow{4}{*}{ 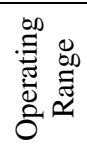 } & locally and region & $72.5 \%$ & $55.0 \%$ & $27.5 \%$ & $12.5 \%$ & $7.5 \%$ & $17.5 \%$ & $10.0 \%$ \\
\hline & country & $79.5 \%$ & $56.4 \%$ & $33.3 \%$ & $7.7 \%$ & $7.7 \%$ & $25.6 \%$ & $2.6 \%$ \\
\hline & EU & $68.2 \%$ & $54.5 \%$ & $27.3 \%$ & $9.1 \%$ & $9.1 \%$ & $40.9 \%$ & $0.0 \%$ \\
\hline & world & $61.5 \%$ & $69.2 \%$ & $38.5 \%$ & $15.4 \%$ & $7.7 \%$ & $38.5 \%$ & $0.0 \%$ \\
\hline
\end{tabular}

Source: Survey results

The conducted study very clearly shows that with increasing computerisation of the company also grows the innovation activity of the companies. This is presented in Table 7.

Table 7. The relationship between the degree of computerization of the company and innovation activities of the company.

\begin{tabular}{|l|c|c|}
\hline \multicolumn{1}{|c|}{ Characteristic } & $\begin{array}{c}\text { design / preparatory activities innovation- } \\
\text { related (last year) }\end{array}$ & $\begin{array}{c}\text { implementation of innovation } \\
\text { (in the last year) }\end{array}$ \\
\hline The company makes use of basic computer software & $29.4 \%$ & $24.0 \%$ \\
\hline $\begin{array}{l}\text { The company uses specialized software tailored to } \\
\text { the business }\end{array}$ & $30.4 \%$ & $36.2 \%$ \\
\hline $\begin{array}{l}\text { The company has implemented an integrated } \\
\text { information system }\end{array}$ & $46.2 \%$ & $46.2 \%$ \\
\hline
\end{tabular}

Source: Survey results

Different forms of innovations can be introduced, with the basic including the improvement and modernisation of existing products, the introduction of new products, the implementation of new technologies or the introduction of new applications for existing technologies/products/services, the improvement/modernisation of the organisation's management process, the improvement/modernisation of the production process, the introduction of new designs of manufactured products, and the introduction of new trademarks/brands on the market. Table 8 below presents the main forms of innovation, depending on the degree of the company's computerisation.

Table 8. The main forms of innovation, depending on the degree of the company computerization.

\begin{tabular}{|c|c|c|c|c|}
\hline \multicolumn{2}{|r|}{ Characteristics } & \multirow{2}{*}{$\begin{array}{l}\text { The company } \\
\text { makes use of } \\
\text { basic computer } \\
\text { software } \\
7.8 \%\end{array}$} & \multirow{2}{*}{$\begin{array}{c}\text { The company uses } \\
\text { specialized } \\
\text { software tailored to } \\
\text { the business }\end{array}$} & \multirow{2}{*}{$\begin{array}{c}\text { The company has } \\
\text { implemented an } \\
\text { integrated } \\
\text { information } \\
\text { system } \\
23.1 \%\end{array}$} \\
\hline \multirow{10}{*}{ 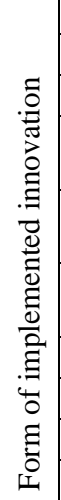 } & Improvement, modernization of existing products & & & \\
\hline & Introduction of new products & $11.8 \%$ & $20.3 \%$ & $38.5 \%$ \\
\hline & Implementation of new technologies & $7.8 \%$ & $18.8 \%$ & $23.1 \%$ \\
\hline & $\begin{array}{l}\text { Introduction of new applications for existing } \\
\text { technologies / products / services }\end{array}$ & $3.9 \%$ & $4.3 \%$ & $7.7 \%$ \\
\hline & $\begin{array}{l}\text { Changing the method of distribution of products / } \\
\text { services }\end{array}$ & $2.0 \%$ & $2.9 \%$ & $0.0 \%$ \\
\hline & $\begin{array}{l}\text { Improvement / modernization of the organization's } \\
\text { management process }\end{array}$ & $2.0 \%$ & $7.2 \%$ & $15.4 \%$ \\
\hline & Improvement / modernization of the production process & $7.8 \%$ & $13.0 \%$ & $15.4 \%$ \\
\hline & Introduction of a new design of manufactured products & $2.0 \%$ & $2.9 \%$ & $7.7 \%$ \\
\hline & Introduction of a new trade mark / brand on the market & $2.0 \%$ & $1.4 \%$ & $7.7 \%$ \\
\hline & Other & $2.0 \%$ & $0.0 \%$ & $0.0 \%$ \\
\hline
\end{tabular}

Source: Survey results

\section{CONCLUSION}

The following conclusions can be drawn based on the study and analysis of their results:

1) the degree of computerisation of the company measured by the advancement of the applied ICTs is similar in rural and urban areas with a slight predominance of enterprises located in urban areas. In the countryside mainly basic technology is used, but in the city we can observe the prevalence of more advanced technologies.

2) the greatest degree of businesses computerisation in rural areas occurs in large companies involved in production and focussing primarily on markets in the European Union 
3 ) in the surveyed companies the most visible difference in the use of modern information technology is observed in the method of accessing the Internet. In rural areas there are more companies with analog Internet connection than in the city. This is due to the problem of underinvestment and shortages of broadband connection in rural areas.

4) Another difference arises from the use of Internet for business. Companies from urban areas more often have a website. On the other hand, it follows from the observation of the use of the Internet for the purpose of running a business, that the majority of such companies are located in rural areas. The Internet allows these companies to eliminate the differences resulting from their unfavourable location and distance to potential customers.

5) Having analysed the relationship between ICTs and innovation in rural areas, one can conclude that there is a strong relationship between the degree of the company's computerisation and its innovativeness. The higher the degree of the company's computerisation, the greater the innovative activity both in the preparation phase of innovations and in their implementation. The above is also confirmed by the analysis of the application of different forms of innovation. The higher the level of computerisation of companies, the more often all kinds of innovation appear in the surveyed enterprises.

ICT development in the modern world, where the dominant role in creating competitive advantages is information is a key task for every company that wants to be competitive not only at the local but also at the global market. The advantage of information results in narrowing the gap between urban and rural areas. It is therefore necessary to improve the infrastructure linked with the connection in rural areas, because the use of outdated technologies will increase in the distance to competitors and reduces or even prevents the use of more innovative solutions. One solution to eliminate the delays of technology in rural areas may be the use of EU funds aimed at improving innovation in the economy, especially in the SME sector.

\section{REFERENCES}

1. Avgerou, C., 2010. Discourses on ICT and Development. Information Technologies \& International Development, Vol. 6, No 3, pp. 3.

2. Balboni, M., Rovira, S., Vergara, S. 2011. ICT in Latin America, A microdata analysis. Chile - United Nations, Santiago, pp. 5.

3. Chen, R. S., Liu, I. F. 2013. Research on the effectiveness of information technology in reducing the Rural - Urban Knowledge Divide, Computers \& Education, Vol. 63, pp. 437-438. http://dx.doi.org/10.1016/j.compedu.2013.01.002

4. Czapiewski, K. L., Kulikowski, R., Bański, J., Bednarek-Szczepańska, M., Mazur, M., Ferenc, M. 2012. The use of ICT in Mazovian agriculture - spatial approach. Rural Studies, Vol. 30, Warsaw, pp. 7-9.

5. Galloway, L., Sanders, J., Deakins, D. 2011. Rural small firms' use of the internet: From global to local, Journal of Rural Studies, Vol. 27, Iss. 3, pp. 255-262. http://dx.doi.org/10.1016/j.jrurstud.2011.05.005

6. Jarosz-Angowska, A., Angowski, M. 2014. Innovation practices of enterprises located in rural areas of Lubelskie Voivodeship. Annals of the PAAAE, Vol. XVI, No. 5, pp. 73.

7. Kijek, A., Kijek, T. 2010. Modelling of innovation diffusion. Operations Research and Decisions, Vol. 20, No. 3-4, pp. 63-68.

8. Macik, R. 2013. Information and Communication Technologies as a decision-making processes moderator of purchasing by consumers. Publishing UMCS, Lublin, pp. 21.

9. Matusiak, K. B. 2011. Innovation and technology transfer. A glossary of terms. PARP, Warsaw, pp. 290.

10. Measuring the Information Society, 2014. International Telecommunication Union, Genewa, pp. 64.

11. Nayak, S. K., Thorat, S. B., Kalyankar, N. V. 2010. Reaching the unreached. A Role of ICT in sustainable rural development. International Journal of Computer Science and Information Security, Vol. 7, No. 1, pp. 220.

12. Ollo-Lopez, A., Aramendia-Muneta, M. E. 2012. ICT impact on competitiveness, innovation and environment, Teleatics and Informatics, Vol. 29, Iss. 2, pp. 205-210. http://dx.doi.org/10.1016/j.tele.2011.08.002

13. Pena, A. I. P., Jamilena, D. M. F., Molina, M. A. R., 2011. Impact of Market Orientation and ICT on the Performance of Rural Smaller Service Enterprises. Journal of Small Business Management, Vol. 49, Iss. 3, pp. 331-360.

14. Sawicka, J., 2010. The Internet as a tool to support the development of entrepreneurship in rural areas - theory and practice. Oeconomia, Vol. 9, Iss. 1, pp. 97.

15. Tarute, A., Gatautis, R. 2014. ICT impact on SMEs performance. Procedia-Social and Behavioral Sciences, Vol. 110, pp. 1218-1225. http://dx.doi.org/10.1016/j.sbspro.2013.12.968

16. Tripathi, A. M., Singh, A. K., Kumar, A., 2012. Information and Communication Technology for Rural Development. International Journal on Computer Sciences and Engineering, Vol. 4, No 5, pp. 824-828. 